Volume 1, Number 2, Juni 2020

Journal of Research on Mathematics Instruction

Link jurnal: http://jrmi.ejournal.unri.ac.id

\title{
THE EFFECTIVENESS OF LEARNING WITH A SCIENTIFIC APPROACH IN THE STAD TYPE COOPERATIVE LEARNING MODEL BASED ON LESSON STUDY ON MATHEMATICS STUDENTS LEARNING ACTIVITIES
}

\author{
Arus Ginanjar ${ }^{1}$, Sehatta Saragih ${ }^{2}$, Kartini ${ }^{3}$ \\ 1 Rokan Hilir Regency School Superintendent, INDONESIA \\ 2,3 Universitas Riau, INDONESIA
}

\section{ARTICLE'S \\ INFORMATION}

\section{Article history:}

Received: May-25-2020

Accepted: Dec-30-2020

\begin{tabular}{ll}
\hline Keywords: & Learning \\
Effectiveness, & Scientific
\end{tabular}

Approach, Cooperative Type

STAD, Lesson Study, Learning

Activities

Corresponding address:

Arus Ginanjar,

E-mail: arusginanjar@gmail.com

\begin{abstract}
This research aimed to reveal the effectiveness of learning with a scientific approach in the STAD type cooperative learning model based on lesson study on mathematics students learning activities. This is a quasi-experimental research where the population was the junior high school students in Rokan Hilir regency which divided into three school levels, namely; high level, middle level and low level. The subject of this research was chosen by applying clustering random sampling method. The second grader of each school was chosen to be the subject of this research by applying purposive sampling. There were experiment and control classes in each subject. The instruments that were used in this research, namely learning media (syllabus, lesson plan and students learning sheet activity) and for the data collection media (question sheet and observation sheet). The design of hypothesis testing of student learning activities in the form of data analysis of student learning activities through statistical tests. Statistical tests used the Kolmogorov-Smirnov data normality test, the Levene variance homogeneity test, the Mann Whitney U difference test, the Independent T-Test, the one-way ANOVA test and continued with the Scheffe test. The result of this research revealed that: students learning activities in the experiment class was better compared to the control class, for every level, there were differences of students learning activities reviewed from school level; and learning with scientific approach in STAD type cooperative learning based o lesson study was effective reviewed from students learning activities. In conclusion, it is proven that learning with a scientific approach in the STAD type cooperative learning model based on lesson study is effective to improve students' learning activities.
\end{abstract}

\section{INTRODUCTION}

Mathematic plays an important role in developing students' potential and science-technology. This role can be manifested through mathematics learning process which is conducted by school which required teachers' attention. Teachers as the spearhead of education who are directly at the forefront of dealing with students are required to have adequate competence. It shows that teachers must be able to have make learning innovation which able to encourage and motivate the students to learn more active, creative and systematize in solving any problem through learning innovations, the students are expected to have a better learning activities until the objective of the learning achieved.

Learning objectives contained in Permendikbud number 58 of 2014 which are in line with the 2013 curriculum in broad outline about the obligation of students to have competence to 
understand concepts, use patterns in problem solving, use reasoning, communicate ideas, have an attitude of respect for the use of mathematics, conduct motoric activities and use simple tools and technology products to do mathematical activities. Aforementioned abilities require critical thinking, systematic, logic, creative and an effective teamwork. Therefore, a teacher must be able to follow up the development of mathematics and always tries to be creative in conducting teaching learning activities.

A creative teacher is able to create an innovative teaching learning activity which will encourage students to be more active during the activities and optimize the learning outcome as well. The optimal teaching learning outcome shows that the students are able to solve problems. Problem solving skill needs several principals as stated in 2013 curriculum which is scientific learning approach.

Permatasari in her research at Batang regency in 2014, revealed that after participating in the learning, the characters were not seen to have the nature of respect, activities, high learning achievement and even tend to be mediocre. Moreover, by conducting the scientific approach, students showed positive attitude toward the learning activities, such as; high learning motivation, high learning activities, respectful attitude and teamwork.

In this current era, teaching learning by applying learning scientific approach is not sufficient. Effort of teacher to educate students is a vital part in achieving planned learning objectives. Hence, even though scientific learning approach has been applied, somehow, it requires an appropriate learning model. One of the cooperative scientific models is type Student Teams Achievement Division (STAD). Salvin opined that STAD is a variation of cooperative learning model which encourage students to motivate and assist each other to master a particular skill that is taught by the teacher [1]. Furthermore, Fitri \& Alfianika stated that this type of learning model can create a better atmosphere and motivate students as well [2].

Cooperative learning type STAD make students to have higher motivation and is an appropriate teaching strategy which encourages the students to be more active during the learning process. When teacher implemented cooperative learning type STAD, subconsciously it has weaknesses and need to be solved. Due to this, teacher may take several efforts for instance studying and reviewing the learning process and it needs several colleagues to work together, share and provide solution in overcoming the weaknesses. This effort is called lesson study.

Lesson study which applied in several schools in Lembang regency showed success, namely having a respectable pedagogic and professional competence where the teachers were able to design learning media individually [3]. Additionally, Putri stated that lesson study learning is essential to improve practice in class, increase creativity, and motivate students [4].

The lesson study approach is the most appropriate approach to address this problem [5]. This approach is really suitable to overcome various problems. In addition, this is also a learning assessment activity carried out by a group of teachers to determine the effectiveness of learning that is carried out continuously to improve the quality of learning [6]. Parallel with that, Vitantri indicated that lesson study is effective to improve teacher competence [7].

Astuti states that the effectiveness of a learning is the level of achievement of teaching goals that have been determined [8]. Hereafter, as opined by Martyanti in 2016, she states that the effectiveness of a learning because learning carried out through a model shows achievement and confidence for students [9].

Learning in this research aimed to determine the effectiveness of scientific learning in the STAD type cooperative learning model based on lesson study. The results showed the effectiveness 
of learning with a scientific approach in the Lesson Study-based STAD type cooperative model of student learning activities.

\section{METHODS}

This is a quasi-experiment research which applied nonequivalent groups pretest-postest design. This research was conducted in Rokan Hilir Regency. The population was junior high school students which grouped into three levels, namely high class, middle class and low class. The sample was randomly chosen by using clustering random sampling technique. Two classes were picked from each school and divide them as control and experiment class. This research ran from March to Mei 2018.

There are three variables in this research, namely independent variable, dependent variable and control variable. The independent variable was learning with a scientific approach in the STAD type cooperative learning model based on lesson study, the dependent variable is student learning activities and the control variable is learning with a scientific approach. The difference in learning activities at the overall level and each level of the school can be known, after students follow the learning.

The stages in conducting this research were: preparation of instruments in the form of learning tools (Syllabus, RPP, LAPD) and data collection instruments (question sheets and observation sheets of implementation of learning); validating the instrument by 3 experts; trial instrument for licensing to school; provide learning in the research sample; research; and data analysis.

Data analysis techniques in this study were done by describing the data obtained. Description of the data in the form of a percentage of student learning activities, both data before treatment and for data after treatment.

The analysis test is carried out, after knowing the assumption test on the level as a whole as well as each school level. Assumptions test in the form of Kolmogov Smirnov data normality test. The proposed hypothesis is: $\mathrm{H}_{0}$ : Data comes from normally distributed sources and $\mathrm{H}_{1}$ : Data comes from sources that are not normally distributed. Test criteria: If the value of sig. (2-way) $>\alpha=$ 0.05 , then $\mathrm{H}_{0}$ is accepted and if the value of sig. (2-way) $<\alpha=0.05$, then $\mathrm{H}_{0}$ is rejected. To find out the homogeneity of variance, a homogeneity test from Lavene was conducted. The test hypotheses given are: $\mathrm{H}_{0}: \sigma_{1}{ }^{2}=\sigma_{1}{ }^{2}$ and $\mathrm{H}_{1}: \sigma_{1}{ }^{2} \neq \sigma_{1}{ }^{2}$, with $\sigma_{1}{ }^{2}=$ Variance of the experimental group or class and $\sigma_{1}{ }^{2}=$ Variance of the control group or class. Test criteria used: if the value of sig. (2-way) $>\alpha=$ 0.05 , then $\mathrm{H}_{0}$ is accepted and if the value of sig. (2-way) $<\alpha=0.05$, then $\mathrm{H}_{0}$ is rejected.

Data that are normally distributed, different tests are carried out namely Independent Test $\mathrm{T}$ Test, the hypothesis is: $\mathrm{H}_{0}: \mu_{1}=\mu_{2}$ and $\mathrm{H}_{0}: \mu_{1}>\mu_{2}$, with, $\mu_{1}=$ percentage of student learning activities in groups or experimental classes and $\mu_{2}=$ percentage of student learning activities in groups or control class. The test criteria are: if the value of sig. (1-way) $>\alpha=0.05$, then $\mathrm{H}_{0}$ is accepted and if the value of sig. (1-way) $<\alpha=0.05$, then $\mathrm{H}_{0}$ is rejected. If the data source is not normally distributed, then the different test uses the Mann Whitney $U$ test. The hypothesis is proposed, as follows: $\mathrm{H}_{0}: \mu_{2}=\mu_{2}$ and $\mathrm{H}: \mu_{1} \neq \mu_{2}$, with, $\mu_{1}=$ percentage of student learning activities in the experimental group or class and $\mu_{2}=$ percentage of student learning activities in the control group or class. The testing criteria used are:

If the value of sig. (1-way) $>\alpha=0.05$, then $\mathrm{H}_{0}$ is accepted and if the value of sig. (1-way) $<\alpha$ $=0.05$, then $\mathrm{H}_{0}$ is rejected. 
Furthermore, to find out the differences in student learning activities, a significance test was conducted for the difference in the percentage of student learning activities between school levels with the one-way ANAVA test. The hypotheses proposed are: $\mathrm{H}: \mu_{1}=\mu_{2}=\mu_{3}$ and $\mathrm{H}_{1}$ : at least one percentage is different from the others, with $\mu_{1}, \mu_{2}, \mu$ berturut, respectively the average student learning outcomes of upper, middle and lower levels . The test criteria are: if the value of sig. (2way) $>\alpha=0.05$, then $\mathrm{H}_{0}$ is accepted and if the value of sig. (2-way) $<\alpha=0.05$, then $\mathrm{H}_{0}$ is rejected. To find out which class of experiment is significantly different, proceed with the Schefee test. Schefee test was conducted to determine whether there are differences in student learning activities that follow learning with a scientific approach in the STAD type cooperative learning model based on lesson study in terms of school level. The calculation is done with the help of the excel for windows program and the SPSS statistical program package version 16.0.

\section{RESULTS AND DISCUSSION}

Mathematics learning uses a scientific approach in the STAD type cooperative model based on lesson study and learning mathematics with a scientific approach in this study carried out in accordance with planned learning activities. Nevertheless, in the learning process found several limitations that can be obstacles in this study. Descriptions of student learning activities at each school level and overall level can be seen in Table 1, as follows:

Table 1. Frequency of Student Learning Activities All Levels

\begin{tabular}{|c|c|c|c|c|c|c|}
\hline \multirow{2}{*}{$\begin{array}{l}\text { Schoo } \\
\text { Level }\end{array}$} & \multicolumn{3}{|c|}{ Experiment } & \multicolumn{3}{|c|}{ Control } \\
\hline & $\mathbf{N}$ & $\Sigma f$ & $\%$ & $\mathbf{N}$ & $\Sigma f$ & $\%$ \\
\hline Upper & 35 & 753 & $89,69 \%$ & 35 & 614 & $73,10 \%$ \\
\hline Middle & 26 & 547 & $87,66 \%$ & 26 & 455 & $72,92 \%$ \\
\hline Lower & 30 & 637 & $88,47 \%$ & 30 & 521 & $72.36 \%$ \\
\hline Rata-rata & & & $88,69 \%$ & & & $72,80 \%$ \\
\hline
\end{tabular}

Table 1 informs that there is a difference in the percentage of learning activities across School Levels. The difference is carried out non-parametric statistical tests. Before conducting the difference test, first test the normality of activity data at the level of the whole learning group (Experiment and Control), respectively as follows:

Table 2. Test Normality in Student Learning Activity Data Based on Overall Level

\begin{tabular}{lllll}
\hline \multicolumn{1}{c}{ Class } & & Dk & Sig. & \multicolumn{1}{c}{$\mathbf{H}_{\mathbf{0}}$} \\
\hline Experiment & 91 & & 0,000 & Rejected \\
Control & 91 & & 0,001 & Rejected \\
\hline
\end{tabular}

In Table 2 informs that the two learning groups, obtained a probability value (sig.) Smaller than 0.05 which means $\mathrm{H}_{0}$ Rejected. That is, the two data groups are not normally distributed.

Table 3. Homogeneity Test Variance Student Learning Activities for Overall Level

\begin{tabular}{ccccc}
\hline Lavene Statistic & dk1 & dk2 & Sig. & $\mathbf{H}_{\mathbf{0}}$ \\
\hline 16,446 & 1 & 180 & 0,000 & Rejected \\
\hline
\end{tabular}

Table 3 informs that the value of sig. $=0,000<0.05=\alpha$ which means $H_{0}$ Rejected. That is, the data of the two learning groups at all levels have non-homogeneous variances. Therefore, testing the differences in student learning activities between the two learning groups, a nonparametric statistical test was performed using the Mann Whitney U test. 
Table 4. Test the Difference in Student Learning Activities for the Overall Level

\begin{tabular}{ccc}
\hline Statistic & Learning Activities & $\mathbf{H}_{\mathbf{0}}$ \\
\hline Mann-Whitney $U$ & 801,500 & \\
Sig. (2-way) & 0,000 & Rejected \\
\hline
\end{tabular}

Table 4 informs that the Sig. (2-way) $=0,000$ smaller than $\alpha=0.05$ which means $H_{0}$ Rejected. Meaning: there are differences in students' learning activities between the two learning groups at the overall level. Conclusion: at the level as a whole, learning activities between students who take learning with a scientific approach in cooperative learning type STAD based on lesson study are better than learning activities of students who take learning with a scientific approach.

Significance test of the differences in learning activities of the three school-level experimental groups was conducted, but the data normality test was first performed. The normality test of students' learning activity data has been done previously and the third level Experiment group data obtained is not normally distributed. Next, test the variance homogeneity of the three groups of experimental groups, as follows:

Table 5. Homogeneity Test Variance Data on Student Learning Activities Experiment Groups Among Levels

\begin{tabular}{ccccc}
\hline Levene Statistic (F) & df1 & df2 & Sig. (2-way) & H $_{\mathbf{0}}$ \\
\hline 0,961 & 2 & 88 & 0,387 & Accepted \\
\hline
\end{tabular}

Table 5 informs that the value of sig. greater than 0.05 , for each school level. This means that the data at all three school levels are homogeneous. According to Mahmudi [10], to conduct ANOVA tests, the terms of homogeneity can be ignored. Furthermore, the significance test is carried out with the one-way ANOVA test, can be seen in Table. 6, as follows:

Table 6. Significance Test of Differences in Student Learning Activity Data

Experiment Groups between the Three Levels

\begin{tabular}{ccccccc}
\hline Source & $\begin{array}{c}\text { Total } \\
\text { Square }\end{array}$ & Dk & $\begin{array}{c}\text { Average } \\
\text { Square }\end{array}$ & F & Sig. (2-way) & $\mathbf{H}_{\mathbf{0}}$ \\
\hline Intra group & 3.500 & 2 & 1,750 & 0,684 & 0,507 & Accepted \\
Inter group & 225.071 & 88 & 0,558 & & & \\
Total & 22.571 & 90 & & & & \\
\hline
\end{tabular}

Table 6 provides information that the value of sig. $=0.507$ is greater than 0.05 , means $\mathrm{H}_{0}$ Accepted. This means that the average student learning activity between the three School Levels is not significantly different.

Table 7. Normality Test Results of Learning Activities Data Based on School Level

\begin{tabular}{ccccc}
\hline School Level & Kelas & Dk & Sig. & $\mathbf{H}_{\mathbf{0}}$ \\
\hline \multirow{2}{*}{ Upper } & Experiment & 35 & 0,000 & Rejected \\
& Control & 35 & 0,017 & Rejected \\
\multirow{2}{*}{ Middle } & Experiment & 26 & 0,024 & Rejected \\
& Control & 26 & 0,200 & Accepted \\
\multirow{2}{*}{ Lower } & Experiment & 30 & 0,099 & Rejected \\
& Control & 30 & 0,005 & Rejected \\
\hline
\end{tabular}

Table 7 informs that the two learning groups probability value (sig.) Is smaller than 0.05 which means $\mathrm{H}_{0}$ Rejected. That is, the two sample data groups are not normally distributed, except for the Control class at the Middle level, obtaining the sig value. $=0,200>0,005$. Meaning: Data comes from normally distributed samples. 
Table 8. Test Homogeneity of Variance Data on Student Learning Activities Both Learning Groups at Each School Level

\begin{tabular}{ccrrrc}
\hline School Level & Lavene Statistic & dk1 & dk2 & Sig. & $\mathbf{H}_{\mathbf{0}}$ \\
\hline Upper & 10,637 & 1 & 68 & 0,002 & Rejected \\
Middle & 1,233 & 1 & 50 & 0,272 & Accepted \\
Lower & 8,470 & 1 & 58 & 0,005 & Rejected \\
\hline
\end{tabular}

Table 8 informs that the upper and lower levels get Sig. smaller than 0.05 which means $\mathrm{H}_{0}$ is rejected. Meaning: top level and bottom level data are not homogeneous. While the level is being scored Sig. greater than 0.05 which means $\mathrm{H}_{0}$ is accepted. Meaning: middle level data is homogeneous.

Table 9. Mann Whitney U Difference Test Students Learning Activities Both Learning Groups at each Level

\begin{tabular}{|c|c|c|c|c|c|}
\hline \multicolumn{6}{|c|}{ Learning Outcome } \\
\hline School Level & Mann-Whitney $U$ & Wilcoxon & $\mathrm{Z}$ & $\begin{array}{c}\text { Sig. } \\
\text { (2-way) }\end{array}$ & $\mathbf{H}_{\mathbf{0}}$ \\
\hline Upper & 85,500 & 715,000 & $-6,242$ & 0,000 & Rejected \\
\hline Middle & 83,500 & 434,500 & $-4,690$ & 0,000 & Rejected \\
\hline Lower & 93,500 & 588,000 & $-5,327$ & 0,000 & Rejected \\
\hline
\end{tabular}

Table 9 informs that each level gets an Asym value. Sig. (2-tailed) is smaller than $\alpha=0.05$ which means $\mathrm{H}_{0}$ Rejected which indicated that there are differences in student learning activities between the two learning groups at each level.

According to the description, the results of the analysis and testing aforementioned that the learning model with a scientific approach in the STAD type cooperative model based on lesson study (experimental) has a positive effect better than learning with a scientific approach (control) at the overall level (Table 4). One positive influence is better learning activities. Furthermore, at each school level, student learning activities in the experimental class were better than student learning activities in the control class (Table 9). Difference and improvement on the conditions of learning activities as mentioned above show the effectiveness of learning with a scientific approach in the STAD type cooperative learning model based on lesson study.

In the literature review, it was explained that the effectiveness of learning is the level of success of student learning outcomes and student learning activities achieved by students after the students after receiving treatment. In the results of this study, treatment in the form of learning with a scientific approach in the STAD type cooperative learning model based on lesson study.

\section{CONCLUSIONS AND SUGGESTIONS}

In conclusion, learning using a scientific approach in the STAD type cooperative learning model based on lesson study shows its effectiveness when viewed from student learning activities in junior high school mathematics subjects.

\section{REFERENCE}

[1] Rusman, Model-model Pembelajaran: Mengembangkan Profesionalisme Guru (Edisi Kedua). Jakarta: PT Raja Grafindo Persada, 2014.

[2] R. Fitri and N. Alfianika, "Effect of Student Teams Achievement Division and Vocabulary Mastery to Reading Comprehension Ability," J. Educ. Learn., vol. 11, no. 4, pp. 453-459, 2017.

[3] T. Herman, "Meningkatkan Kualitas Pembelajaran Matematika Sekolah Dasar Melalui Lesson 
Study," J. Pendidik., vol. 13, no. 1, pp. 56-63, 2012.

[4] I. Putri, Atmazaki, and Syahrul R, "Pelaksnaan Lesson Study Dalam Pembelajaran Bahasa Indonesia Siswa Kelas VII.5 MTs N Lubuk Buaya Padang," J. Bahasa, Sastra dan Pembelajaran, vol. 1, no. 1, pp. 108-117, 2013.

[5] A. H. Amirullah and Z. H. Iksan, "Lesson Study: An Approach to Increase the Competency of Out-of-Field Mathematics Teacher in Building the Students Conceptual Understanding in Learning Mathematics," J. Educ. Sci., vol. 2, no. 2, pp. 1-13, 2018.

[6] C. Lewis, "Does Lesson Study Have a Future in the United States?," Nagoya J. Educ. Hum. Dev., vol. 1, pp. 1-23, 2002.

[7] C. A. Vitantri and T. M. Asriningsih, "Efektivitas Lesson Study pada Peningkatan Kompetensi Calon Guru Matematika," JMPM J. Mat. dan Pendidik. Mat., vol. 1, no. 1, pp. 2333, 2016.

[8] R. D. Astuti and A. M. Abadi, "Keefektifan Pembelajaran JIGSAW dan TAI Ditinjau dari Kemampuan Penalaran dan Sikap Belajar Matematika Siswa," J. Ris. Pendidik. Mat., vol. 2, no. 2, pp. 235-250, 2015.

[9] A. Martyanti, "Keefektifan Pendekatan Problem Solving dengan Setting STAD dan TAI Ditinjau dari Prestasi dan Self-Confidence," J. Ris. Pendidik. Mat., vol. 3, no. 1, pp. 1-15, 2016.

[10] Kartini, "Peningkatan Kemampuan Berpikir Kritis dan Kreatif serta Belief Matematis Siswa Sekolah Menengah Atas Melalui Pembelajaran Inkuiri Model Alberta," 2011.

\section{BIOGRAPHY}

Arus Ginanjar

He was born in the city of Magelang on Friday, July 24, 1970. Researcher completed his Strata-1 (S1) in 2005 and strata-2 (S-2) in 2019. Phone Number 08126849079 and email arusginanjar@gmail.com

Sehatta Saragih

Lecturer in the Universitas Riau. He obtained his Strata-3 (S3) in Universitas Pendidikan Indonesia. Email: ssehatta@yahoo.com

Kartini

Lecturer in the Universitas Riau. She obtained her Strata-3 (S3) in Universitas Pendidikan Indonesia. Email: tin_baa@yahoo.com 